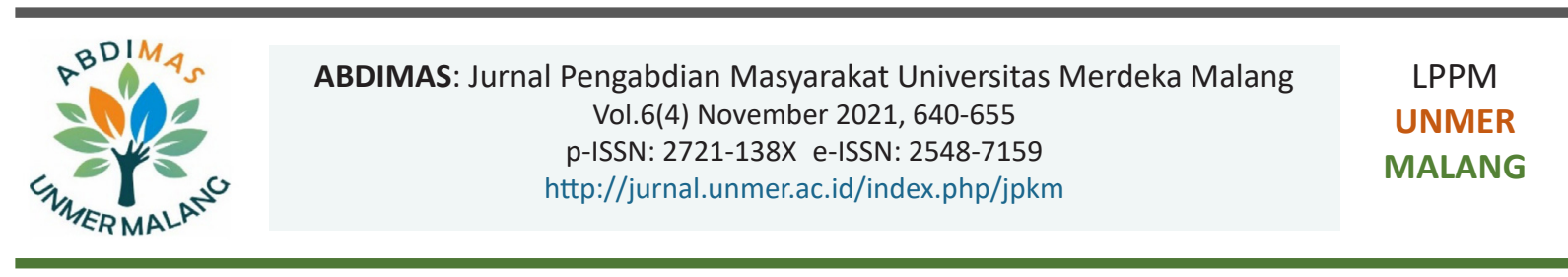

\title{
Raising the awareness of privacy on the use of internet technology among adolescents
}

\section{Peningkatan kesadaran privasi penggunaan teknologi internet di kalangan remaja}

\author{
Muhammad Yusuf Abror ${ }^{1}$, Miftha Pratiwi², Muchammad Yustian Yusa', Farisha Sestri \\ Musdalifah'2, Krisna Murti² \\ ${ }^{1}$ Departemen Ilmu Hubungan Internasional, ²Departemen Ilmu Komunikasi, Fakultas Ilmu Sosial dan Ilmu Politik, \\ Universitas Sriwijaya
}

Jl. Masjid Al Gazali, Bukit Lama, Palembang, 30128, Indonesia

ARTICLE INFO
Received: 2021-04-13
Revised: 2021-06-26
Accepted: 2021-07-28
Keywords:
Adolescent, Human
security, Privacy, SDGs,
Technology

Technology

\begin{abstract}
Sustainable Development Goals (SDGs) is the global agreement agreed by United Nation member countries. The agreement aims to assure fair and equitable development throughout the world. SDGs consist of 17 goals, which one of the goals is about information, communication, and technology (ICT). The principle of SDGs target is to make all countries benefit from the use of ICT including Indonesia. The massive use of ICT in Indonesia, especially within the young generation somehow triggers the possibility of cybercrime. It is necessary to increase awareness of the dangers of cyberspace, specifically regarding the use of personal data. Referring to that, this event conducts a program to increase the understanding and awareness of Junior and Senior High School students to be more careful when using their gadgets such as mobile phones, laptops, and computers, and etc. The method of analysis used in this research is qualitative which is a desk study and quantitative through the questionnaire. The results achieved in this service is the increased awareness of adolescents in Junior and Senior High School about the importance of personal data's security on the internet so that students can be more aware and selective when accessing various websites. websites.
\end{abstract}

(C)2021 Published by University of Merdeka Malang. This is an open access article distributed under the CC BY-SA 4.0 license (https://creativecommons.org/licenses/by-sa/4.0/)

How to cite: Abror, M. Y., Pratiwi, M., Yusa, M. Y., Musdalifah, F. S., \& Murti, K. (2021). Raising the awareness of privacy on the use of internet technology among adolescents. Abdimas: Jurnal Pengabdian Masyarakat Universitas Merdeka Malang, 6(4), 640-655. https://doi.org/10.26905/abdimas.v6i4.5697

\section{PENDAHULUAN}

Internet saat ini sudah menjadi kebutuhan dasar bagi mayoritas masyarakat dunia. Pengguna yang ingin terkoneksi dengan internet harus memiliki pemahaman mengenai teknologi, informasi, dan komunikasi. Tujuan utamanya adalah untuk mempermudah kehidupan manusia sehingga manusia bisa selalu mengaktualisasi diri menjadi lebih baik lagi. Pentingnya performa teknologi, informasi, dan 
komunikasi (TIK) dalam kehidupan sehari-hari membuat negara-negara di dunia bersepakat untuk mempercepat penyebaran kehidupan digitalisasi tersebut.

Proses penyebaran digitalisasi ini masuk di dalam program yang dicanangkan oleh PBB melalui Sustainable Development Goals (SDGs) atau biasa disebut dengan Tujuan Pembangunan Berkelanjutan yang diikuti oleh 193 negara di dunia. Program SDGs ini merupakan lanjutan dari program terdahulu yang bernama Millenium Develompent Goals (MDGs) yang telah dimulai pada awal tahun 2000 dan berakhir pada tahun 2015. Setelah program MDGs selesai pada tahun 2015, PBB melanjutkan program tersebut ke dalam program baru yang bernama SDGs pada 25 September 2015 dan efektif pada tahun 2016 hingga tahun 2030 (Morton et al., 2017). Seiring dengan dukungan dunia internasional melalui PBB terhadap tujuan perkembangan berkelanjutan, termasuk di dalamnya perkembangan teknologi, informasi dan komunikasi yang semakin meningkat maka kesadaran akan keamanan data pribadi dalam akses internet harus ditingkatkan.

Pada umumnya masyarakat dunia yang telah terdigitalisasi menjadikan internet sebagai media yang berperan dalam kehidupan. Berdasarkan data dari Internet World Stats jumlah pengguna internet seluruh dunia mencapai 4,9 miliar dari total jumlah penduduk dunia 7,7 miliar orang (Internet World Stats, 2020). Berdasarkan data tersebut maka sekitar 63\% penduduk dunia sudah mengakses internet dan menjadi tren yang terus dibutuhkan.

Masifnya pengguna internet saat ini karena manusia sudah cukup ketergantungan dengan kemudahan yang diberikan, diantaranya adalah mencari informasi, membeli barang, bermain permainan, berbisnis, pendidikan, mengakses layanan kesehatan, hiburan, dan sosialisasi (Sarwar \& Soomro, 2013). Berdasarkan hasil survei dari Asosiasi Penyelenggara Jasa Internet Indonesia, penetrasi pengguna internet di Indonesia pada tahun 2017 berjumlah 143,26 juta jiwa penduduk dengan durasi penggunaan rata-rata 3-7 jam (Aprilia et al., 2020). Masih menurut APJII, 75,5\% penggunanya adalah remaja (Aprilia et al., 2020). Berdasarkan data tersebut membuat penggunaan teknologi informasi dan komunikasi menjadi kebutuhan bagi masyarakat Indonesia terutama para remaja. Sehingga internet telah menjadi bagian dari kehidupan sehari-hari bagi masyarakat. Teknologi, informasi dan komunikasi juga menjadi peran yang vital serta memiliki kontribusi terhadap SDGs sehingga industri ini memiliki potensi yang besar bagi perkembangan dunia (Jones et al., 2017).

Meskipun penggunaan internet meningkat dan dibutuhkan banyak orang. Sudah seharusnya sebagai pengguna teknologi informasi harus lebih waspada dan sadar bahwa data pribadi akan selalu menjadi incaran pihak-pihak terkait. Jika pihak-pihak terkait tersebut memiliki niat yang buruk maka data pengguna dapat disalahgunakan. Dengan demikian, kewaspadaan penggunaan internet harus selalu menjadi prioritas karena banyak pihak yang menginginkan data pribadi.

Penghimpunan data yang dilakukan pihak-pihak tertentu menjadi big data yang biasanya digunakan untuk kepentingan bisnis. Mesin pencari akan membaca perilaku konsumsi pada masyarakat. Misalnya suatu website belanja daring memberikan diskon belanja kepada konsumennya namun dengan syarat mengisi formulir seperti nama lengkap, nomor telpon, alamat surel, ataupun kota tempat tinggal. Hal tersebut merupakan salah satu cara yang digunakan oleh pengelola website untuk mendapatkan data penggunanya secara sukarela. 
ABDIMAS: Jurnal Pengabdian Masyarakat Universitas Merdeka Malang Volume 6, No. 4, November 2021: 640-655

Ancaman lainnya adalah masuknya malware atau malicous software dalam sistem internet pengguna. Malware merupakan perangkat lunak yang dibuat untuk melakukan aktivitas berbahaya sehingga berdampak merugikan bagi para korbannya seperti penyadapan, pencurian data pribadi, sampai penyusupan pada perangkat korban (Cahyanto et al.,, 2017). Maka, data diri pengguna internet bisa dalam bahaya karena terdapat peluang disalahgunakan untuk kepentingan tertentu.

Dengan demikian, timbul pertanyaan bagaimana tingkat kesadaran pengguna internet dari bahaya penyalahgunaan data pribadi terutama para remaja karena berdasarkan survei APJII 75,5\% pengguna internet adalah remaja. Berdasarkan data dari APJII tersebut menjadi landasan bagi tim pengabdi untuk melakukan survei terhadap para remaja mengenai bagaimana tingkat kesadaran terhadap privasi data pribadi dalam penggunaan internet. Maka tim pengabdian melakukan observasi lapangan ke kedua mitra dan didapati bahwa mitra sedang memiliki intensitas dalam penggunaan internet terutama untuk kegiatan pembelajaran jarak jauh dan akses website untuk mencari data bahan sekolah. Sehingga dalam kegiatan pengabdian ini penulis mengambil sampel dari 24 orang dari sekolah SMPN 1 Palembang dan SMAN 8 Palembang. Pengambilan sampel tersebut dilakukan ketika tim pengabdian melakukan seminar kepada ke dua mitra. Adapun dua mitra tersebut berasal dari dua wilayah yang berbeda namun masih dalam satu kota yang sama yaitu Kota Palembang. Kota Palembang secara umum terbelah oleh Sungai Musi sehingga secara langsung membagi kota ini menjadi dua wilayah yaitu, wilayah Ulu dan wilayah Illir. Wilayah Ulu berada pada bagian Selatan Palembang dan berada pada luar dari pusat kota. Wilayah Illir berada pada bagian Utara Palembang dan berada pada pusat kota. Adapun untuk remaja SMP berasal dari wilayah Ilir dan remaja SMA berasal dari wilayah Ulu.

Kedua mitra pada masa Pandemi COVID-19 melakukan kegiatan pembelajaran jarak jauh yaitu bersifat daring sehingga para siswa lebih sering menggunakan internet daripada sebelumnya. Di lain sisi, selain penggunaan internet sebagai media belajar jarak jauh dengan sekolah asal, para remaja sekolah juga menggunakan internet untuk mengerjakan tugas dan melakukan pencarian sumber pembelajaran melalui internet serta beragam aktivitas dunia maya lainnya. Beragam website dikunjungi oleh para siswa untuk mendapatkan beragam informasi. Tidak semua website aman, meskipun aman terkadang ada yang merekam jejak digital pengguna untuk dijadikan big data mereka dalam hal marketing. Agar data pribadi dalam berselancar aman dan terkendali, maka dibutuhkan kesadaran penuh dari para remaja untuk lebih berhati-hati.

Berdasarkan pemaparan dalam sub latar belakang ini penulis menyampaikan pemaparan dalam bentuk seminar agar permasalahan peretasan data diri dapat dihindari di tengah tingginya frekuensi penggunaan internet oleh remaja. Hal ini karena pengguna internet di Indonesia terutama para remaja belum diiringi dengan kesadaran terhadap privasi data pribadi. Meskipun program SDGs merupakan program yang sangat baik untuk meningkatkan digitalisasi masyarakat dunia, namun bahaya dari hal tersebut dapat menyerang penggunanya jika tidak waspada dan berhati-hati. Dengan demikian melalui penulisan artikel adalah memberikan pendampingan kepada siswa SMPN 1 dan SMAN 8 untuk meningkatkan kesadaran dalam menjaga privasi data pribadi pada saat besarnya dukungan negaranegara di dunia melalui SDGs untuk program digitalisasi. Hal ini penting dilakukan karena data pribadi dapat diperjualbelikan dan penyalahgunaan bisa terjadi. 


\section{METODE}

Pelaksanaan pengabdian ini ditujukan kepada 24 orang dari SMPN 1 dan SMAN 8 di Kota Palembang. Hasil pada pra-survei di antaranya yaitu ke dua sekolah melakukan kegiatan pembelajaran jarak jauh. Sehingga proses pembelajaran dilakukan secara daring maka sekolah juga tidak bisa mengumpulkan para siswa untuk dilakukan pengabdian luring. Dengan demikian, pihak sekolah dan pihak tim pengabdian sepakat untuk melakukan proses pengabdian dengan cara daring melalui Zoom. Adapun Pengabdian masyarakat ini menggunakan empat metode dalam melengkapi data, yang disajikan pada Gambar 1 .

\begin{tabular}{|c|c|}
\hline Observasi & $\begin{array}{l}\text { - Observasi ke lapangan dalam hal ini menghubungi SMPN } 1 \text { dan SMAN } 8 \\
\text { - Kunjungan ke sekolah memberikan penjelasan maksud kegiatan }\end{array}$ \\
\hline & $\begin{array}{l}\text {-Studi kepustakaan menjadi dasar pikir dalam penulisan artikel. } \\
\text {-Tinjauan pustaka terdahulu digunakan untuk memperkuat isi penulisan artikel }\end{array}$ \\
\hline $\mathrm{ap}$ & $\begin{array}{l}\text {-Pemaparan dilakukan dalam bentuk webinar kepada para peserta } \\
\text {-Pemateri melakukan presentasi kepada peserta }\end{array}$ \\
\hline 510 & $\begin{array}{l}\text { - Pada saat acara berlangsung peserta mengisi kuesioner sebagai bukti penguat data } \\
\text { - Kuesioner memperdalam pemahaman terhadap peserta terhadap pemaparan yang } \\
\text { telah dilaksanakan tim pengabdian }\end{array}$ \\
\hline Evaluasi & $\begin{array}{l}\text {-Melakukan evaluasi dalam bentuk tanya-jawab dan menganalisis hasil dari } \\
\text { kuesioner yang telah disebarkan. }\end{array}$ \\
\hline
\end{tabular}

Gambar 1. Metode pelaksanaan program pengabdian masyarakat

\section{Metode kuantitatif}

Tim pengabdian melakukan metode kuantitatif untuk mengumpulkan data primer seperti melakukan observasi lapangan yang dilakukan pada 18 November 2020 yang bertujuan untuk melihat kondisi sekolah di SMPN 1 dan SMAN 8 Palembang. Pelaksanaannya dengan langsung mendatangi sekolah dan berkomunikasi langsung dengan pihak kedua mitra. Ternyata gambaran yang didapat oleh tim adalah proses pengajaran dilakukan secara daring sehingga penggunaan internet meningkat dalam mengakses beragam website dan tentu ini mendukung asumsi awal dari tim pengabdian bahwa para remaja sering menggunakan internet dalam kehidupan sehari-hari. Sehingga mereka harus lebih waspada dalam penggunaannya untuk melindungi data diri. 
ABDIMAS: Jurnal Pengabdian Masyarakat Universitas Merdeka Malang Volume 6, No. 4, November 2021: 640-655

Selain obeservasi lapangan langsung ke sekolah, tim juga menyebarkan kuesioner pada 28 November 2020 yang tercantum di dalam link https://docs.google.com/forms/d/1mZSIpgUi6aZPU21Fo rPsQ9Bis31nQXFbmmoYyTvCzS8/ kepada para siswa dengan tujuan melihat tingkat kesadaran terhadap privasi data pribadi. Pelaksanaan survei melalui kuesioner disebarkan pada saat tim pengabdian melakukan pemaparan mengenai SDGs dan privasi data diri kepada siswa melalui daring dengan dibantu media Zoom. Hal ini bertujuan untuk menggambarkan bagaimana pemahaman siswa mengenai bahaya privasi mereka di dunia maya.

Melalui data yang didapatkan dari kuesioner, tim pengabdian melakukan evaluasi terhadap pemahaman dan kesadaran peserta mengenai privasi data diri mereka. Evaluasi ini menjadi dasar justifikasi yang menjadi asumsi awal tim pengabdian bahwa remaja masih kurang memiliki kesadaran akan bahaya penyalahgunaan data pribadi pada dunia maya. Sehingga menjadi hasil yang dapat digunakan dalam penulisan artikel ini sebagai data acuan.

\section{Metode kualitatif}

Tim pengabdian menggunakan data sekunder untuk mendukung justifikasi yang ditulis dalam artikel ini. Desk study menjadi metode yang digunakan yaitu melakukan analisis terhadap berbagai jurnal penelitian sebelumnya dan website yang mendukung tulisan ini. Dengan demikian, metode kualitatif ini menjadi pendukung utama dalam mengelaborasi data yang didapatkan pada metode kuantitatif. Sehingga terjadi triangulasi yang saling mendukung ke dua metode agar lebih relevan dan akurat.

Tim juga melakukan pemaparan materi pada 28 November 2020 kepada siswa sekolah bertujuan untuk memberikan pemahaman mengenai SDGs dan privasi data pribadi. Teknik ceramah menjadi cara untuk menggambarkan dan menjabarkan mengenai ancaman privasi data yang akan timbul bagi para pengguna yang tidak berhati-hati dalam penggunaan internet. Pemaparan ini bertujuan agar peserta dapat mengerti bagaimana penyebaran internet melalului TIK sudah menyebar begitu luas yang didukung oleh program SDGs. Maka dibutuhkan kesadaran yang lebih kuat agar mewaspadai setiap aktivitas di dunia maya.

Pemaparan dilakukan oleh tim pengabdian kepada para peserta seminar melalui pertemuan virtual di aplikasi Zoom. Hal ini untuk mengedepankan efektifitas kegiatan di tengah pandemi COVID-19. Sehingga semua materi dalam program pengabdian disampaikan melalui daring kepada para peserta. Setelah pemaparan oleh materi selesai maka dilanjutkan metode berbagi pengalaman dan tanya-jawab serta para siswa mengisi kuesioner yang dijadikan data primer bagi peneliti.

\section{HASIL DAN PEMBAHASAN}

\section{Hasil}

Penulisan artikel ini merupakan hasil dari kegiatan pengabdian kepada masyarakat yang menggunakan beberapa tahap pelaksanaan selama kegiatan berlangsung. Tahapan kegiatan yang dilakukan menggunakan metode kualitatif dan metode kuantitatif seperti yang telah dijelaskan pada paragraf sebelumnya. Kedua metode tersebut menjadi penting dilakukan agar hasil yang diperoleh menjadi lebih valid dan dipercaya secara ilmiah. 


\section{Tahapan pelaksanaan}

Tahapan pelaksanaan menjadi indikator yang penting dalam proes pengabdian karena ini akan menertibkan kegiatan serta mempermudah dalam pengumpulan data penulisan artikel, adapun tahapannya sebagai berikut.

\section{Observasi lapangan}

Observasi lapangan menjadi tahapan awal yang penting adapun sasaran dalam pengabdian ini adalah siswa sekolah. Agar proses penulisan artikel ini berjalan lancar maka dibutuhkan sasaran yang sesuai dengan tema pengabdian. Tim Pengabdian melakukan observasi lapangan di SMPN 1 dan SMAN 8 Palembang sebagai langkah awal proses pengabdian (Gambar 2). Di SMPN 1 tim disambut oleh guru bidang hubungan masyarakat dan di SMAN 8 disambut oleh kepada sekolah. Tim juga melakukan prasurvei untuk melihat kondisi sekolah dan siswa yang menjadi objek utama pengabdian.
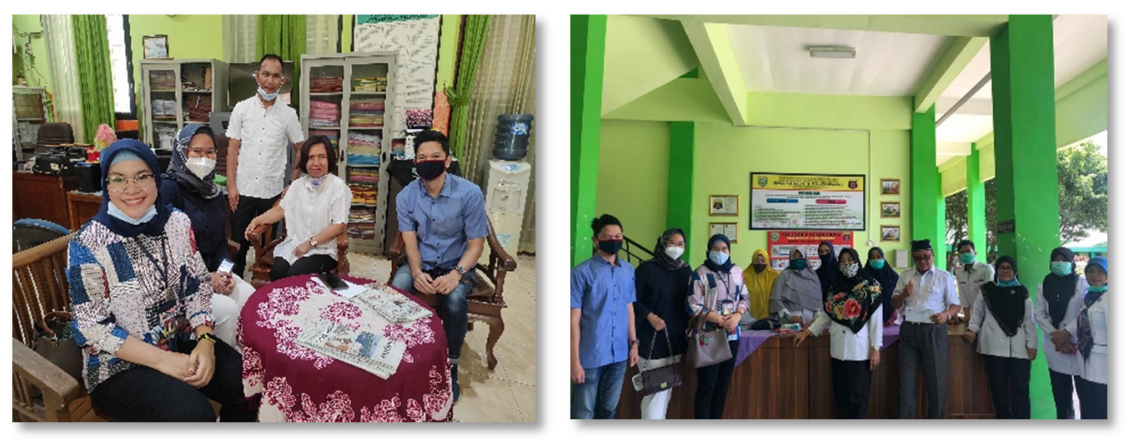

Gambar 2. Kunjungan dan observasi ke sekolah SMAN 8 dan SMPN 1

Pada tahap observasi awal, tim diterima dengan baik oleh pihak sekolah dan disambut antusias karena para siswa saat ini memang memiliki frekuensi yang tinggi dalam menggunakan internet. Apalagi pada masa pandemi yang menuntut pihak sekolah dan siswa untuk sering mengakses internet. Sehingga proses pembelajaran dan situasi di sekolah juga saat ini minim interaksi seacara langsung dengan siswa.

\section{Pemaparan webinar}

Setelah adanya kesepakatan antara pihak sekolah dengan tim pengabdian kepada masyarakat FISIP Universitas Sriwijaya, maka dilanjutkan dengan pemaparan materi dalam bentuk webinar melalui aplikasi Zoom pada waktu yang telah disepakati bersama. Acara kegiatan dilakukan pada 24 Desember 2020 bersama rekan sejawat dan mahasiswa (Gambar 3). Selain itu peserta masuk ke ruang Zoom melalui gawai mereka masing-masing. 
ABDIMAS: Jurnal Pengabdian Masyarakat Universitas Merdeka Malang Volume 6, No. 4, November 2021: 640-655
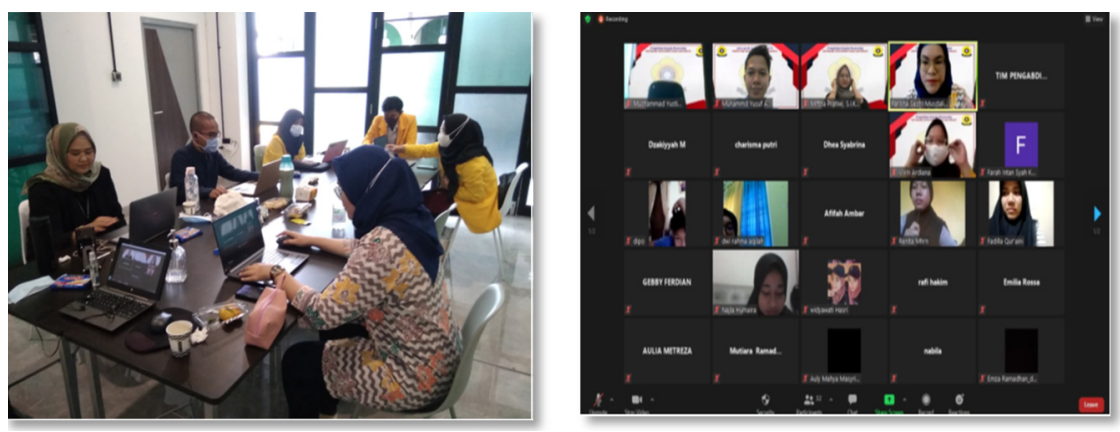

Gambar 3. Pemaparan materi webinar

Pemaparan dilakukan oleh lima pembicara yang berasal dari dosen lingkungan Universitas Sriwijaya. Pada Gambar 2 di atas dapat dilihat proses pemaparan oleh para dosen sebagai pemateri dalam kegiatan pengabdian ini. Tim melakukan kegiatan tersebut dalam satu ruangan bersama untuk memudahkan koordinasi antar dosen. Siswa yang menjadi peserta menyimak isi pemaparan sebagai bentuk edukasi kepada mereka. Pembahasan dalam pemaparan yang disampaikan mulai dari penjelasan mengenai peranan SDGs dalam pembangunan industri dan penyebarluasan teknologi hingga pada penjabaran mengenai pentingnya perlindungan data diri dalam penggunaan internet. Sehingga para remaja yang sering bersinggungan dengan teknologi, informasi dan komunikasi dapat lebih meningkatkan kesadaran akan adanya ancaman penyalahgunaan data pengguna internet.

\section{Penyebaran kuesioner}

Penyebaran kuesioner dilakukan di sela-sela berlangsungnya kegiatan pemaparan materi. Hal ini sekaligus untuk melihat bagaimana pemahaman dan kesadaran para siswa mengenai kewaspadaan akan adanya penyalahgunaan privasi data diri di dunia maya. Kuesioner tersebut kemudian dianalisis dan dikaji oleh tim pengabdian.

\section{Penutup}

Penyampaian materi yang telah dilakukan menjadi bahan diskusi antara pemateri dan peserta. Sehingga pada akhir acara diadakan sesi tanya-jawab untuk melihat pemahaman mereka terhadap materi. Dengan demikian, evaluasi siswa peserta webinar dilakukan dalam dua bentuk yaitu kuesioner dan tanya-jawab interaktif.

\section{Pembahasan}

Teknologi informasi dan komunikasi (TIK) masuk menjadi bagian dari percepatan Tujuan Pembangunan Berkelanjutan/SDGs. SDGs sendiri mengakomodir 17 tujuan (goals), yaitu: (1) Tanpa kemiskina; (2) Tanpa kelaparan; (3) Kehidupan sehat dan sejahtera; (4) Pendidikan berkualitas; (5) Kesetaraan gender; (6) Air bersih dan sanitasi layak; (7) Energi bersih dan terjangkau; (8) Pekerjaan layak 
dan pertumbuhan ekonomi; (9) Industri, inovasi dan infrastruktur; (10) Berkurangnya kesenjangan; (11) Kota dan pemukiman yang berkelanjutan; (12) Konsumsi dan produksi yang bertanggung jawab; (13) Penanganan dan perubahan iklim; (14) Ekosistem laut; (15) Ekosistem daratan; (16) Perdamaian, keadilan, dan kelembagaan tangguh; dan (17) Kemitraan untuk mencapai tujuan. Tujuh belas tujuan tersebut memiliki cakupan yang sangat luas dan merangkul banyak sektor dan aktor. Membuat semua pihak atau stakeholders dari atas hingga bawah saling terkait dan mendukung. Hal ini karena program SDGs adalah program hajat hidup orang banyak sehingga melibatkan banyak komunitas.

Indonesia sebagai negara yang ikut bergabung dalam program SDGs membentuk dasar hukum yang tertuang dalam Perpres Nomor 59 Tahun 2017 yang berisi komitmen pemerintah dalam pencapaian 17 tujuan SDGs. Di antara 17 tujuan tersebut poin yang relevan dalam pengabdian ini tercantum di dalam tujuan ke 9. Program tujuan ke 9 tertulis tentang infrastruktur, industri, dan inovasi. Digali lebih dalam lagi bahwa teknologi informasi dan komunikasi masuk ke dalam sub tujuan 9.c yang dijabarkan dalam indikator 9.c.1* mengenai proporsi penduduk yang terlayani mobile broadband; 9.c1.(a) tentang proporsi individu menguasai/memiliki telepon genggam; 9.c.1.(b) proporsi individu pengguna internet (Bappenas, 2017). Sehingga target teknologi informasi dan komunikasi juga menjadi tujuan pemerintah yaitu harus meningkatkan akses digitalisasi tersebut ke seluruh Indonesia.

Maka, dibutuhkan komitmen pemerintah selain peningkatan akses terhadap internet, juga dibutuhkan perlindungan data diri pengguna internet agar data masyarakat tidak disalahgunakan oleh pihak yang tidak bertanggungjawab. Data diri merupakan bagian dari privasi masyarakat yang tidak boleh terekspos ke publik tanpa izin pengguna. Terlebih lagi digunakan untuk hal-hal komersil atau tindak kriminal oknum tertentu. Dengan adanya program dari Perserikatan Bangsa-Bangsa (PBB) melalui SDGs yang didukung pemerintah Indonesia maka harus diiringi dengan perlindungan hukum mengenai privasi perlindungan data diri dalam dunia maya. Sehingga pemerintah harus segera mengesahkan RUU Perlindungan Data Diri. Selain perlindungan dari pemerintah melalui UU, pengguna internet juga harus berperan aktif dalam melindungi data dirinya sendiri dan harus selektif.

Hal ini dikarenakan masih adanya penyalahgunaan teknologi yang dapat dilihat dari oknum yang melakukan kegiatan peretasan data dan pengguna teknologi yang menggunakan teknologi dengan tidak hati-hati sehingga terjadi peretasan data privasi yang dapat disalahgunakan. Maka, dalam pengabdian ini penulis fokus terhadap kesadaran penggunaan teknologi telepon pintar yang terhubung ke internet kususnya pada pengguna remaja sekolah. Remaja sekolah memiliki waktu yang lebih banyak dalam mengakses internet.

Selain kesadaran pengguna internet untuk mengamankan data pribadinya, peran pemerintah sebagai penyelenggara negara harus membentuk regulasi yang melindungi data pengguna internet dari penyalahgunaan pihak yang tidak bertanggungjawab. Indonesia sebagai negara hukum harus memberikan kepastian hukum kepada rakyatnya, hukum dibuat harus memiliki tiga asas dasar yaitu, kepastian hukum, keadilan, dan kemanfaatan sesuai dengan UU No. 37 tahun 2004 (Wijayanta, 2014). Berdasarkan tiga ide dasar tersebut maka keamanan privasi pengguna teknologi, informasi, dan komunikasi juga harus dapat terjamin sehingga memberikan kepastian hukum. 
ABDIMAS: Jurnal Pengabdian Masyarakat Universitas Merdeka Malang Volume 6, No. 4, November 2021: 640-655

Privasi merupakan tentang pribadi diri yang tidak ingin disampaikan kepada publik, baik kehidupan pribadi maupun data pribadi. Jika pada masa sebelum digitalisasi manusia secara umum dapat tertutup pribadi dirinya dari dunia luar, maka setelah era digitalisasi setiap individu dapat terekspos jati dirinya ke dunia luar. Tentu ini melanggar hak asasi manusia jika data diri yang terekspos adalah sesuatu yang tidak ingin disampaikan kepada publik. Hak asasi yang dimaksud di sini berdasarkan The Universal Declaration of Human Rights (UDHR) yaitu, setiap manusia berhak memperoleh kehidupan yang layak, kebebasan, keselamatan, dan kebahagian pribadi (Wilujeng, 2013). Sehingga semestinya setiap individu dapat dijamin keamanan dan keselamatannya dalam mengakses internet tanpa takut adanya pencurian data pribadi dan penyalahgunaan privasi dari pengguna internet. Selain itu, konsep keamanan seperti yang disampaikan oleh The United Nations Development Programme (UNDP) yaitu, freedom from fear and freedom from want yang bermakna bahwa dua term tersebut menjadi tujuan akhir dari konsep keamanan. Maka akan menghasilkan absence of personal violence and absence of structural violence (Hidayat, 2017). Dalam konteks pengabdian ini, internet dan media sosial juga termasuk dalam ranah publik yang seharusnya bebas dari ancaman diri pribadi pengguna internet yang pada akhirnya pengguna internet dapat terbebas dari penyalahgunaan data pribadi.

Salah satu organisasi yang sadar akan keamanan pribadi masyarakatnya adalah Organization for Economic Cooperation dan Development (OECD). Selain OECD, Uni Eropa sebagai lembaga supranasional juga telah mengedepankan perlindungan data diri melalui European Data Protection (Lukács, 2017). Regulasi tersebut menjadi suatu jaminan bahwa data pengguna internet dapat dilindungi dengan baik. Sehingga dapat memperkecil celah penyalahgunaan data pribadi.

Berdasarkan dua contoh tersebut peran pemerintah sebagai regulator dibutuhkan untuk menjamin dan melindungi masyarakatnya dari bahaya ancaman penyalahgunaan data pribadi. Dikarenakan saat ini RUU Perlindungan Data Diri di Indonesia masih belum disahkan, maka peran aktif dari pengguna internet menjadi bagian penting untuk perlindungan diri. Data pribadi dapat dimaknai sebagai apapun yang berhubungan kepada individu seperti nama, nomor identitas, data lokasi, bentuk fisik, online identifier, psikologi, genetik, mental, ekonomi, budaya atau sosial dari setiap individu (Yuniarti, 2019). Bocornya data pribadi bisa melalui e-commerce dan bahkan dari instansi pemerintah sendiri. Dampak dari bocornya data pribadi di antaranya yaitu tawaran secara langsung (direct marketing) produkproduk keuangan seperti asuransi dan pinjaman tanpa agunan yang membuat masyarakat pengguna internet terganggu (Rosadi \& Pratama, 2018). Website yang tidak bertanggungjawab akan menyimpan data pribadi melalui aktivasi cookies sehingga email dan nama pengguna internet akan terbaca serta tersimpan. Seperti contohnya Google yang memiliki layanan iklan daring dalam Google AdWords, secara tidak langsung mengontrol jaringan iklan yang akan ditampilkan kepada pengguna (Cherry, 2014). Sehingga terkadang muncul pop-up iklan di beranda website yang digunakan.

Ancaman privasi data semakin kuat ketika terjadi pengumpulan data yang masif pengguna internet. Data ini bisa diperjual-belikan kepada pihak tertentu untuk memanfaatkannya secara komersil ataupun tindakan kriminal seperti penipuan. Data-data ini dapat terkumpul menjadi satu kesatuan big data, sehingga dapat digunakan untuk membaca perilaku manusia (Davidowitz, 2017). Maka, tidak heran jika pengguna internet akan terganggu dengan muncul pop-up iklan di beranda mereka karena riwayat perjalanan dalam kunjungan suatu e-commerce telah direkam.

Invasi data lainnya yang juga mengancam pengguna internet adalah adanya malware (malicious software), terutama bagi pengguna ponsel pintar dengan sistem operasi Android, di mana sistem operasi 
tersebut bersifat open source (Zeng et al., 2017). Sehingga para pengguna internet sudah seharusnya bijak dalam memilih aplikasi yang akan diinstal pada telepon selulernya. Hal ini demi keamanan dan keselamatan data pribadi diri. Aplikasi meminta akses ke data pribadi pengguna telepon seluler sehingga bisa mengakses foto dan video di telepon seluler mereka. Ini menjadi ancaman yang serius jika developer aplikasi tersebut memiliki niat tidak baik dalam penggunaan data pribadi diri.

Sebenarnya pengguna telepon pintar secara sukarela memberikan data pribadi mereka kepada pihak lain melalui akses internetnya. Survei APJII menunjukkan bahwa pengguna internet memiliki tiga alasan utama dalam menggunakan internet, di antaranya adalah untuk berkomunikasi, media sosial, dan mencari informasi terkait pekerjaan. Meskipun banyak kebutuhan yang dapat diakomodir oleh internet untuk akses ke media sosial, komunikasi, dan mencari pekeraan, namun tetap dibutuhkan keputusan yang selektif dalam memilih website atau memberikan data pribadi. Pengguna harus memastikan terlebih dahulu bahwa website yang diakses akan bertanggungjawab atas data yang telah diberikan. Beberapa website yang diakses biasanya memiliki fitur location check in dan unggah data pribadi baik foto maupun identitas diri. Tentu hal ini akan berdampak hilangnya privasi data diri jika website yang di akses tidak memiliki tanggung jawab yang penuh komitmen akan data penggunanya.

Jika dilihat dari tingkat kesadaran mengenai pengumpulan data pribadi di internet, pengguna usia muda lebih paham dan sadar akan adanya ancaman pribadi dari penggunaan internet (Halim, 2015; Graeff \& Harmon, 2002). Meskipun para remaja memiliki kesadaraan akan privasi namun terkadang memiliki tingkat yang kewaspadaan yang masih rendah. Seperti misalnya ketika ada term and condition pada aplikasi yang akan diinstal, beberapa di antara mereka tidak membacanya dengan baik dan hanya klik agree/next dan instal. Padahal dengan membaca persyaratan yang diberlakukan oleh suatu aplikator membuat pengguna dapat memahami apa saja data yang akan mungkin diambil oleh pihak pengembang. Maka dari itu, secara ilmiah pengabdian ini berusaha mengisi ruang kosong mengenai kesadaran privasi dalam penggunaan internet di kalangan remaja, khususnya pada siswa SMPN 1 Palembang dan SMAN 8 Palembang Provinsi Sumatera Selatan. Selain itu, untuk mengkonfirmasi kesesuaian data kualitatif dengan data kauntitatif.

Dari penjabaran di atas dapat dilihat urgensi pemahaman terhadap privasi diri menjadi penting karena remaja sekolah merupakan individu yang memiliki rasa penasaran yang tinggi sehingga akan mencoba-coba hal-hal baru yang belum tentu hal baru itu aman. Sama halnya seperti mengakses website dan instal aplikasi baru, dibutuhkan sikap yang bijak dan kritis dalam menerima hal baru agar data diri menjadi aman. Mitra yang menjadi relasi tim pengabdian mendapatkan informasi baru bagi siswa peserta sehingga dapat meningkatkan kesadaran bahaya penyalahgunaan data pribadi di dunia maya. Berdasarkan data yang dihimpun melalui kuesioner sebagai metode kuantitatif yang digunakan oleh penulis yaitu siswa sekolah sering menggunakan fasilitas internet untuk akses berbagai keperluan namun masih kurang akan kesadaraan bahaya di dunia maya dalam hal bocornya data pribadi. Metode kuantitatif tersebut kemudian dianalisis ke dalam metode kualitatif bahwa pengabdian ini memberikan kemanfaatan bagi para peserta siswa karena pengetahuan mereka terhadap keamanan privasi data pribadi masih cukup kurang. Maka asas kemanfaatan dalam pengabdian ini membuka pemikiran para siswa agar lebih waspada dalam mengakses internet.

Setelah diadakan webinar oleh tim pengabdian masyarakat Universitas Sriwijaya, penulis ingin melihat bagaimana tingkat kesadaran remaja dalam menggunakan teknologi, informasi dan komunikasi 
ABDIMAS: Jurnal Pengabdian Masyarakat Universitas Merdeka Malang Volume 6, No. 4, November 2021: 640-655

yang terhubung dengan internet. Tingkat kesadaran dari peserta menjadi indikator analisis untuk membuat kesimpulan akhir dalam artikel ini. Maka dilakukan pengumpulan data primer melalui kuesioner dari 24 orang remaja sekolah dengan hasil yang dijabarkan sebagai berikut.

Pada Gambar 4, peserta diminta untuk memilih opsi apakah sering mengganti kata kunci secara berkala atau tidak. Sebanyak 58,3\% peserta tidak melakukan penggantian kata kunci secara berkala dan tentu ini menjadi hal yang rentan terhadap pembajakan akun pribadi. Remaja sekolah ternyata masih tidak terlalu rutin dalam mengganti password semua akun mereka yang terhubung dengan internet. Sedangkan sebesar 41,7\% secara berkala mengganti kata kunci mereka. Ini merupakan bentuk fenomena yang baik karena hampir separuh peserta memiliki kesadaraan privasi data meskipun ini masih terbilang kurang. Penggunaan internet yang cukup sering harus diiringi dengan perubahan password secara berkala untuk memberikan keamanan bagi akun pribadi.
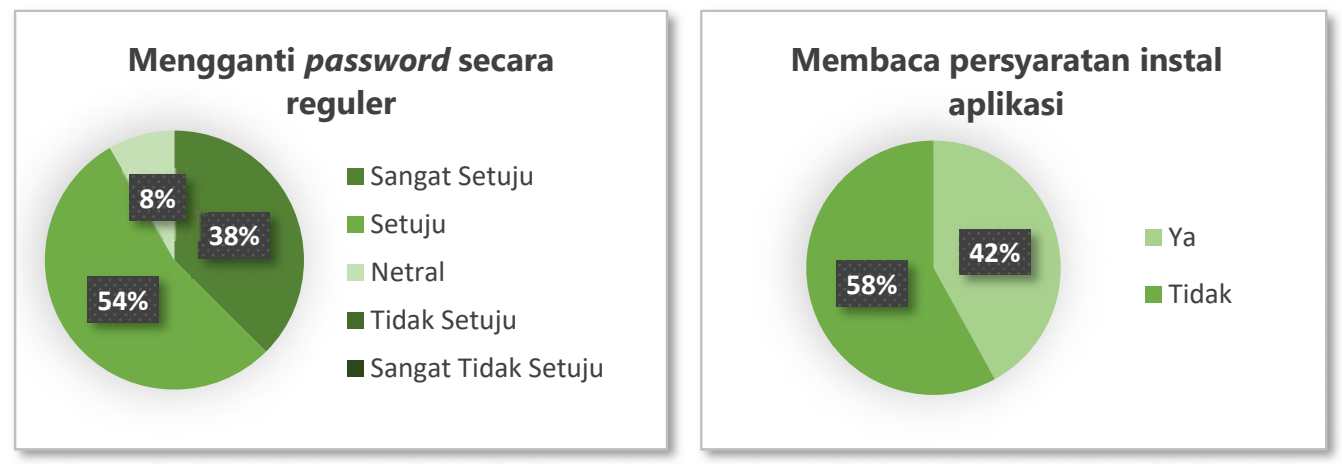

Gambar 4. Mengganti password secara reguler

Gambar 5. Membaca persyaratan instal aplikasi

Meskipun remaja sekolah masih cenderung tidak acuh untuk mengganti password dengan rutin. Pada Gambar 5 ternyata remaja masih memiliki kesadaran untuk membaca persyaratan yang diberikan pihak aplikator ketika akan instal suatu aplikasi yaitu sebesar $91,7 \%$ dan netral sebanyak $8,3 \%$. Ini tentu menjadi temuan yang positif dan menunjukkan bahwa tingkat literasi pada remaja di dunia maya begitu tinggi.
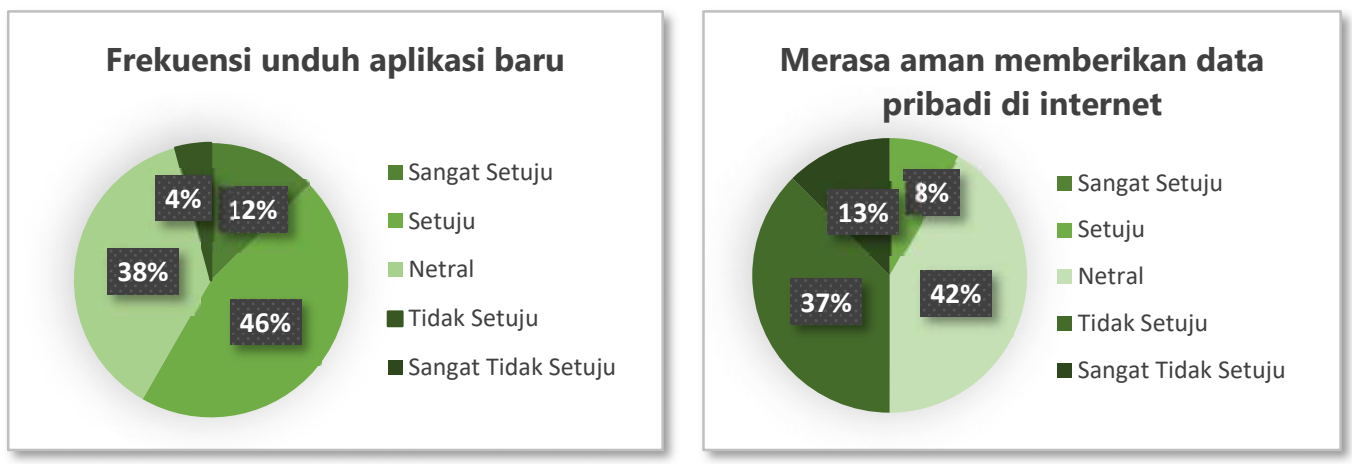

Gambar 6. Frekuensi unduh aplikasi baru

Gambar 7. Merasa aman memberikan data pribadi di internet 
Selanjutnya pada Gambar 6 menjelaskan frekuensi remaja dalam mengunduh aplikasi baru masih sangat tinggi yaitu sebesar $58,3 \%$ dan yang netral $37,5 \%$. Hal ini dikarenakan tingkat penasaran remaja yang tinggi dalam mengeksplor hal-hal baru dan bersifat kekinian. Namun tingkat unduh aplikasi yang tinggi ini seharusnya diiringi juga dengan kesadaran terhadap bahaya bocornya data diri. Sedangkan frekuensi pengunduhan aplikasi yang sedikit masih berada di angka 4,2\% dan tentu angka tersebut masih sangat kecil. Sehingga seharusnya siswa kembali menyeleksi aplikasi yang memiliki tingkat kredibilitas tinggi agar data pribadi tidak disalahgunakan.
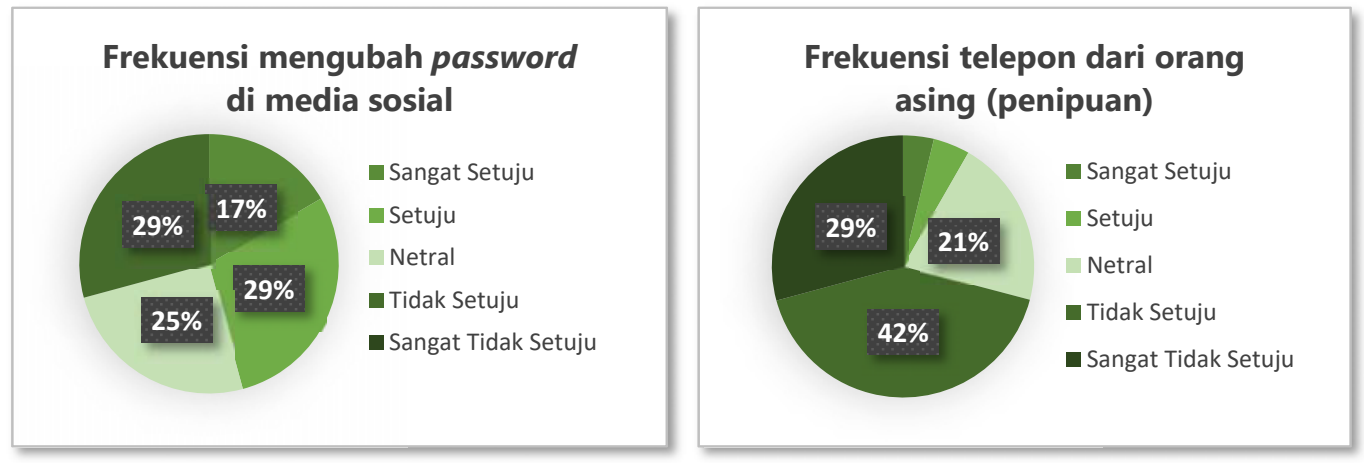

Gambar 8. Frekuensi mengubah password di media sosial Gambar 9. Frekuensi telepon dari orang asing (penipuan)

Ternyata data pada Gambar 7 tidak aman ketika diminta memberikan data pribadi di internet. Tentu ini merupakan hasil yang positif sehingga para remaja dapat waspada dari penyalahgunaan internet ketika mereka sedang melakukan kegiatan yang berhubungan dengan internet. Sudah seharusnya juga bagi pengguna internet dan aplikasi untuk selalu memikir ulang dari setiap software yang akan diinstal. Namun di lain sisi masih terdapat $41,7 \%$ peserta yang menyatakan diri mereka netral dan 8,3\% yang merasa aman. Sehingga ini menjadi pekerjaan rumah bersama para akademisi dan stakeholder terkait untuk terus menggencarkan akan perlindungan data pribadi. Sudah seharusnya juga RUU Perlindungan Data Pribadi segera disahkan untuk melindungi data diri para pengguna internet.

Selain cenderung tidak mengganti password secara rutin seperti yang dijabarkan pada diagram satu. Sebanyak $29,2 \%$ siswa juga merasa tidak terlalu perlu mengganti password, khususnya media sosial mereka secara rutin. Sedangkan 25\% peserta netral dan hanya $45,9 \%$ saja yang setuju bahwa perlu mengubah kata kunci pada media sosial siswa. Pernyataan diagram satu berkolerasi dengan Gambar 8. Sehingga dapat diambil kesimpulan bahwa remaja cenderung tidak menyukai berganti-ganti password secara berkala. Padahal mengganti kata kunci media sosial ini mendukung keamanan data diri mereka.

Dari Gambar 9 sebesar 70.9\% dapat diketahui bahwa para siswa sekolah tidak mendapatkan telepon dari orang asing yang bermaksud akan menipu. Sehingga dapat dilihat mereka cukup bisa mengamankan data pribadi dari ancaman pihak-pihak yang tidak bertanggung jawab di dunia maya. Namun, masih terdapat 20,8\% yang netral dan 8,3\% pernah dihubungi penipu, artinya porsi tersebut harus diberikan edukasi agar tidak terjebak penipuan oleh pihak-pihak jahat. Secara keseluruhan sebenarnya menjadi keharusan bagi akademisi dan berbagai pihak untuk memberikan edukasi untuk selalu waspada ancaman-ancaman dari berbagai pihak yang menyalahgunakan data pribadi. 
ABDIMAS: Jurnal Pengabdian Masyarakat Universitas Merdeka Malang Volume 6, No. 4, November 2021: 640-655

Namun demikian, melalui Gambar 10 menunjukkan meskipun sebanyak 70,9\% siswa remaja sekolah tidak mendapatkan telepon penipuan. Namun mereka tidak dapat menghindari SMS penipuan dari ponsel mereka, tercatat sebanyak 37,5\% pernah mendapatkan SMS penipuan. Sedangkan 20,8\% lainnya netral dan 37,3\% tidak pernah mendapatkan SMS penipuan. Data tersebut memperlihatkan masih terdapat celah yang bisa disusupi para penipu kepada para remaja. Sehingga harus berhati-hati untuk tidak percaya begitu saja dari SMS yang datang tanpa konfirmasi kepada pihak yang berwenang.
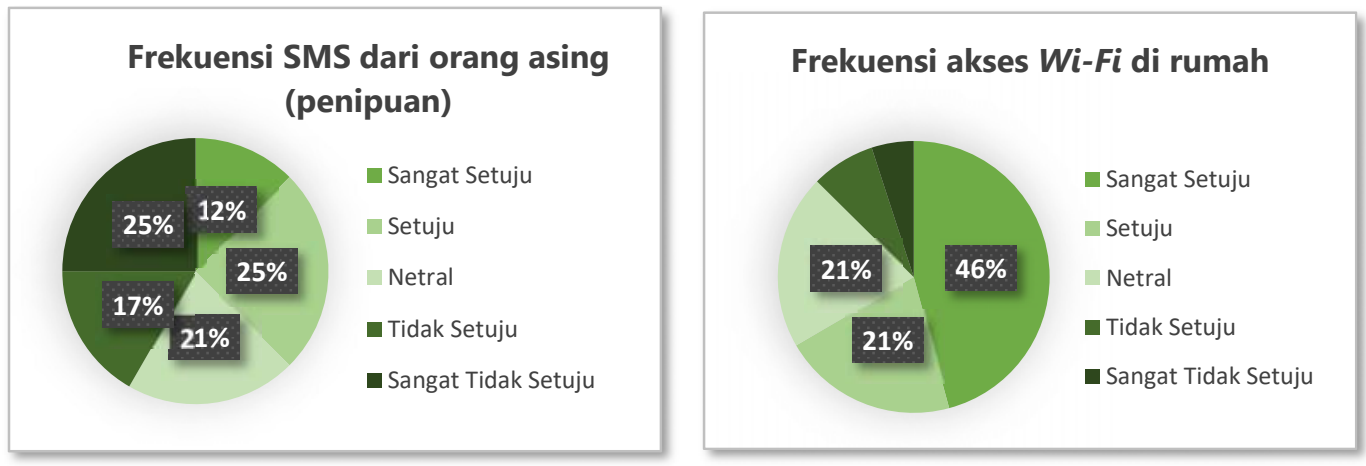

Gambar 10. Frekuensi SMS dari orang asing (penipuan)

Gambar 11. Frekuensi akses Wi-Fi di rumah

Data Gambar 11 menunjukkan bahwa para siswa lebih sering menggunakan Wi-Fi di rumah yaitu sebesar 66,6\%. Ini menjadi hasil yang positif karena mereka menggunakan Wi-Fi rumah yang jaringannya lebih aman daripada Wi-Fi di tempat publik seperti kafe dan mall. Sedangkan 20,8\% memilih netral dan 12,6\% tidak menggunakan Wi-Fi dirumah. Meskpun mayoritas siswa menggunakan Wi-Fi dirumah, mereka juga harus selalu berhati-hati dalam mengakses website karena bisa terjadi pencurian data dan dapat disalahgunakan.

Gambar 12 menunjukkan 37\% siswa mengakses Wi-Fi di tempat umum dan sebesar 20,8\% netral. Sedangkan yang tidak pernah mengakses Wi-Fi di tempat umum sebesar $41,2 \%$ lebih sedikit daripada yang tidak mengakses Wi-Fi di tempat umum. Sehingga didapati bahwa siswa lebih nyaman ketika mereka mengguna Wi-Fi di rumah. Maka dapat ditarik kesimpulan para siswa merasa kurang aman dan nyaman ketika menggunakan Wi-Fi di tempat umum.
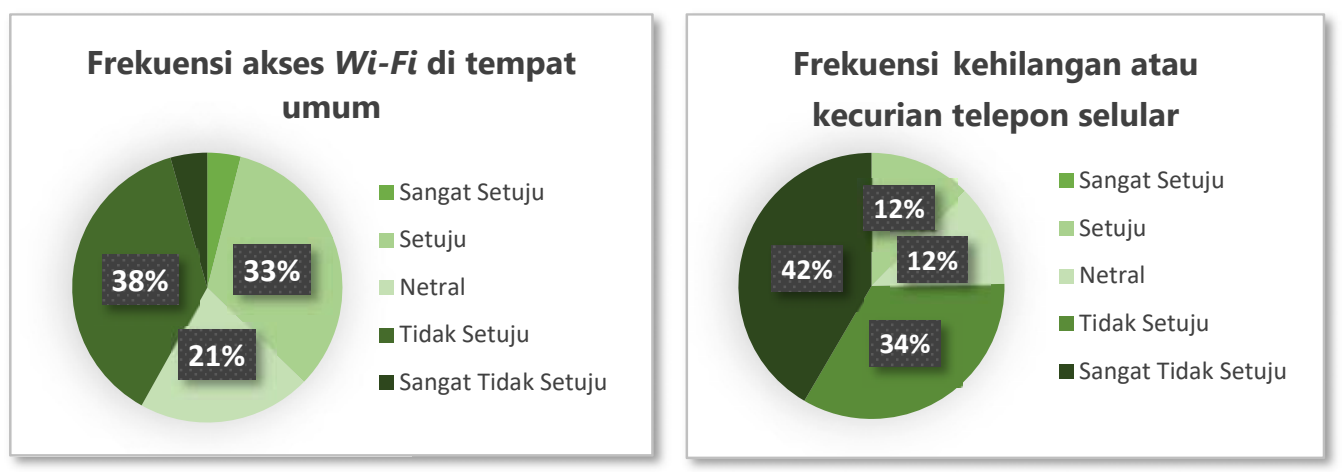

Gambar 12. Frekuensi akses Wi-Fi di tempat umum Gambar 13. Frekuensi kehilangan atau kecurian telepon selular 


\section{Raising the awareness of privacy on the use of internet technology among adolescents \\ Muhammad Yusuf Abror, Miftha Pratiwi, Muchammad Yustian Yusa, Farisha Sestri Musdalifah, Krisna Murti}

Berdasarkan data pada Gambar 13 bahwa remaja masih sangat perhatian dan bertanggung jawab atas ponsel yang mereka pergunakan sehingga masih jarang terjadi kehilangan dan pencurian pada ponsel mereka yaitu hanya $12.5 \%$. Hal ini memperlihatkan bahwa ponsel merupakan bagian penting dari data diri yang berada di dalamnya. Sedangkan yang tidak pernah kecurian sebesar 75\% dan yang netral $12.5 \%$. Sehingga privasi di dalam ponsel harus dijaga dengan baik.

\section{SIMPULAN DAN SARAN}

Kemajuan digitalisasi yang didukung juga oleh program dari Perserikatan Bangsa-Bangsa (PBB) membuat seluruh dunia kian makin terkoneksi satu dengan lainnya. Membuat penggunaan teknologi informasi dan komunikasi yang berhubungan dengan internet semakin meningkat. Kuatnya arus digitalisasi ini sudah seharusnya juga diiringi dengan kesadaran akan privasi diri di dunia internet agar selalu menjadi prioritas. Agar data diri tidak disalahgunakan oleh pihak yang tidak bertanggung jawab. Melalui kegiatan sosialisasi pengabdian kepada masyarakat Universitas Sriwijaya yang dilaksanakan di SMAN 8 Palembang dan SMPN 1 Palembang bertujuan untuk memberikan pemahaman kepada para siswa tentang keamanan privasi data. Pengabdian ini berlatarbelakang pada kondisi dimana remaja sudah sangat melekat dengan gawai yang terhubung dengan internet namun dirasa masih kurang waspada terhadap keamanan data pribadi. Melalui kegiatan pengabdian tersebut kemudian Tim Pengabdian melakukan survei melalui kuesioner untuk melihat sejauh mana kesadaran remaja mengenai data pribadi dalam penggunaan internet. Sehingga dapat diambil kesimpulan bahwa benar siswa pelajar memang sering menggunakan internet namun kesadaran akan privasi data diri masih kurang baik. Maka asumsi dasar penulis tadi terkonfirmasi melalui metode kuantitatif (kuesioner) sehingga tujuan untuk memberikan edukasi dalam bentuk webinar kepada para peserta menjadi relevan dan menghasilkan pemahaman dari para peserta mengenai perlunya kewaspadaan menjaga dari pribadi di dunia maya yang dianalisis berdasarkan metode kualitatif. Kesimpulan yang diperoleh adalah tingkat kesadaran remaja tentang keamanan diri dalam mengakses data ke internet masih kurang dan setelah pemaparan melalui webinar pelajar lebih waspada untuk mengunduh data dan mengunggah data. Selain itu juga para remaja dapat lebih selektif dalam memasuki situs internet. Para siswa yang memiliki banyak teman dan aktif di komunitasnya dapat menyebarkan dan menyampaikan ilmu yang didapatkan dalam seminar pengabdian ini. Sehingga remaja Indonesia akan lebih aktif dan sadar mengenai keamanan data pribadi mereka.

Meskipun kesadaran akan privasi diri di internet adalah kurang namun cenderung ke arah baik, sehingga masih terdapat celah yang jika lengah menjadi masalah bagi data diri pelajar, yaitu masih kurangnya keinginan untuk mengubah password akun secara rutin. Maka saran yang dapat diberikan adalah jangan enggan untuk mengubah password secara rutin, misalnya seminggu sekali atau sebulan sekali. Selain itu, pemerintahjuga harus segara mengesahkan RUU Perlindungan Data Diri agar memberikan keamanan dalam mengakses internet bagi para penggunannya. Hal ini bertujuan untuk membuat akun pribadi lebih aman. Sedangkan untuk pengabdi selanjutnya disarankan untuk memberikan tutorial cara mengakses internet yang lebih teknis kepada para peserta agar lebih memahami cara menghindari lama website atau link yang kemungkinan memiliki kerentanan pembocoran data pribadi. 
ABDIMAS: Jurnal Pengabdian Masyarakat Universitas Merdeka Malang Volume 6, No. 4, November 2021: 640-655

\section{UCAPAN TERIMA KASIH}

Penulis tim pengabdian kepada masyarakat FISIP Universitas Sriwijaya mengucapkan terimakasih kepada Universitas Sriwijaya atas dukungan penuhnya baik dalam bentuk materil dan juga dukungan non-materil. Hal tersebut sangat membuat proses pengabdian dan penulisan artikel ini dengan lancar.

\section{DAFTAR PUSTAKA}

Aprilia, R., Sriati, A., \& Hendrawati, S. (2020). Tingkat kecanduan media sosial pada remaja. Journal of Nursing Care, 3(1), 41-53. https://doi.org/10.24198/jnc.v3i1.26928

Bappenas. (2017). Tentang metadata indikator Tujuan Pembangunan Berkelanjutan (TPB)/Sustainable Development Goals (SDGs) Indonesia 2019.

Cahyanto, T. A., Wahanggara, V., \& Ramadana, D. (2017). Analisis dan deteksi malware menggunakan metode malware analisis dinamis dan malware analisis statis. Jurnal Sistem \& Teknologi Informasi Indonesia, 2(1), 19-30. https://10.32528/justindo.v2i1.1037

Cherry, D. (2014). The basic of digital privacy. Syngress.

Davidowitz, S. S. (2017). Everybody lies, big data dan apa yang diungkapkan internet tentang siapa kita sesungguhnya. Jakarta: PT Gramedia Pustaka Utama.

Graeff, T. R., \&Harmon, S.(2002). Collecting and using personal data:consumers' awareness and concerns. Journal of Consumer Merketing, 19(4), 302-318. https://doi.org/10.1108/07363760210433627

Halim, N. A. (2015). Penggunaan media internet di kalangan remaja untuk mengembangkan pemahaman keislaman. Jurnal Risalah, 26(3), 132-150. http://dx.doi.org/10.24014/jdr.v26i3.1270

Hidayat, R. A., (2017). Keamanan manusia dalam perspektif studi keamanan kritis terkait perang intranegara. Intermestic: Journal of International Studies, (1)2, 108-129.

http://dx.doi.org/10.24198/intermestic.v1n2.3

Internet World Stats. (2020). World internet usage and population statistics 2020 year-Q3 estimates. https://www.internetworldstats.com/stats.htm.

Jones, P., Wynn, M., Hillier, D., \& Comfort, D. (2017). The sustainable development goals and information and communication technologies. Indonesian Journal of Sustainability Accounting and Management, 1(1), 1-15. https://doi.org/10.28992/ijsam.v1i1.22

Lukács, A. (2017). To post, or not to post - that is the question: employee monitoring and employees' right to data protection. Masaryk University Journal of Law and Technology, 11(2), 256-262. https://doi.org/10.5817/MUJLT2017-2-1

Morton, S., Pencheon, D., \& Squires, N. (2017). Sustainable Development Goals (SDGs), and their implementation: A national global framework for health, development and equity needs a systems approach at every level. British Medical Bulletin, 124(1), 81-90. https://doi.org/10.1093/ $\mathrm{bmb} / \mathrm{ldx} 031$

Peraturan Presiden Nomor 59 Tahun 2017 tentang Pelaksanaan Pencapaian Tujuan Pembangunan Berkelanjutan.

Rosadi, S. D., \& Pratama, G. G. (2018). Perlindungan privasi dan data pribadi dalam era ekonomi digital di Indonesia. Veritas Et Justitia, (4)1, 88-110. https://doi.org/10.25123/vej.v4i1.2916 
Raising the awareness of privacy on the use of internet technology among adolescents

Muhammad Yusuf Abror, Miftha Pratiwi, Muchammad Yustian Yusa, Farisha Sestri Musdalifah, Krisna Murti

Sarwar, M., \& Soomro, T. R. (2013). Impact of smartphone's on society. European Journal of Scientific Research 98(2), 216-226.

Wijayanta, T. (2014). Asas kepastian hukum, keadilan dan kemanfaatan dalam kaitannya dengan putusan kepailitan pengadilan niaga. Jurnal Dinamika Hukum, 14(2), 216-226.

https://doi.org/10.20884/1.jdh.2014.14.2.291

Wilujeng, S. R. (2013). Hak asasi manusia: Tinjauan dari aspek historis dan yuridis. Humanika, 18(2). https://doi.org/10.14710/humanika.18.2

Yuniarti, S. (2019). Perlindungan hukum data pribadi di Indonesia. Jurnal Becoss, 1(1), 147-154. https://doi.org/10.21512/becossjournal.v1i1.6030

Zeng, Z. L., Ni, Y. T., \& Lin, B. G. (2017). Permissions based android malware stealing privacy data detection. Prosiding, International Conference on Electronic and Information Technology (ICEIT 2017). https://doi.org/10.12783/dtcse/iceit2017/19871 